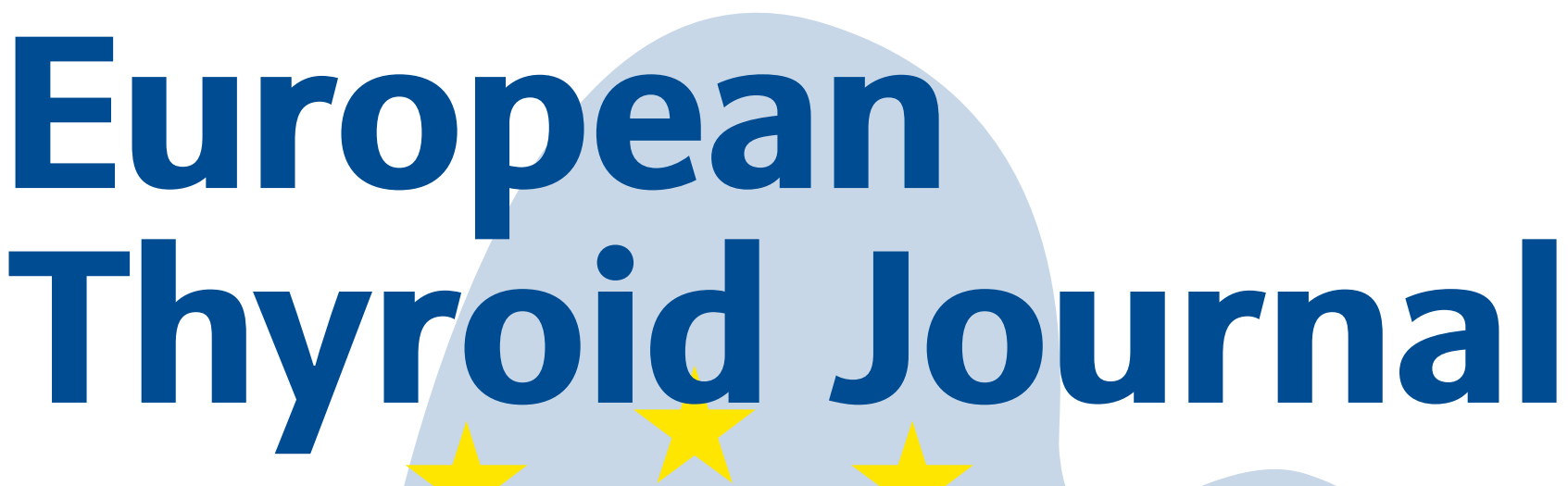

Official Journal of the European Thyroid Association

Medical and Scientific Publishers Basel $\cdot$ Freiburg · Paris .

London · New York .

New Delhi · Bangkok $\cdot$ Beijing

Tokyo $\cdot$ Kuala Lumpur .

Singapore $\cdot$ Sydney
KARGER 
Become a member of the European Thyroid Association

The European Thyroid

Association's aims are

to promote knowledge

in the thyroid field

(fundamental and clinical)

and improve knowledge

of the thyroid gland and

its diseases.

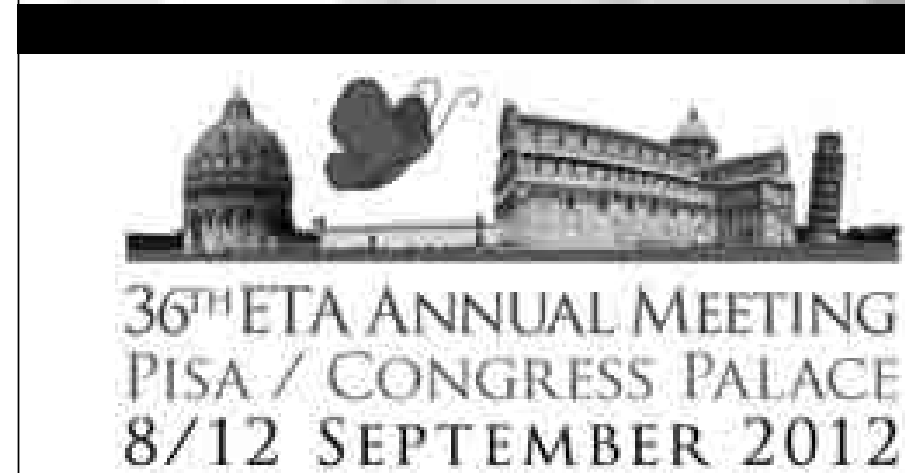

Details of the 36th Annual Meeting can be found on the official website: www.eta2012.0rg

We look forward to seeing you in PISA!

ETA Standing Office

EndoScience Endokrinologie Service GmbH

Hopfengartenweg 19, 90518 Altdorf, Germany $\quad T+49(0) 9187-97424-15 \quad F+49$ (0)9187-97424-75 euro-thyroid-assoc@endoscience.de

All ETA Members benefit through:

low annual fees for young investigators

reduced registration fees at the Annual Meetings

free access to the new European Thyroid Journal online version

reduced fees for the European Thyroid Journal printed version

ETA Members Search

ETA Interest Search

Prizes and Awards

Several Prizes are awarded during the Annual Meeting

\section{Travel Grants}

A number of travel grants are available to Young Investigators who are ETA Members and under 35.

Full details under www.eurothyroid.com 
Editor-in-Chief

Wilmar M. Wiersinga, Amsterdam

\section{Associate Editors}

Josef Koehrle, Berlin

(Basic Thyroidology)

Peter Laurberg, Aalborg

(Clinical Thyroidology)
Luca Persani, Milan

(Translational Thyroidology)

Furio Pacini, Siena

(Thyroid Cancer)

\section{Editorial Board}

Maria Alevizaki, Athens

Ana Aranda, Madrid

Rebecca Bahn, Rochester, Minn.

Paul Banga, London

Luigi Bartalena, Varese

Bernadette Biondi, Naples

Anita Boelen, Amsterdam

Georg Brabant, Lubeck

Henning Dralle, Halle

Murat Erdogan, Ankara

Valentin Fadeyev, Moscow

Ulla Feldt-Rasmussen, Copenhagen

Laszlo Hegedus, Odense

George J. Kahaly, Mainz

Rui Maciel, São Paolo

Ana Luiza Maia, Porto Alegre
Jens Mittag, Stockholm

Ralf Paschke, Leipzig

Simon Pearce, Newcastle-upon-Tyne

Robin Peeters, Rotterdam

Kris Poppe, Bruxelles

Samuel Refetoff, Chicago, Ill.

Jacques Samarut, Lyon

Pilar Santisteban, Madrid

Jan Smit, Leiden

Mark Vanderpump, London

Theo Visser, Rotterdam

Paolo Vitti, Pisa

Graham Williams, London

Shunichi Yamashita, Nagasaki

Mariastella Zannini, Naples 


\section{European Thyroid Journal}

\section{Aims and Scope}

The European Thyroid Journal publishes papers reporting original research in basic, translational and clinical thyroidology. Original contributions cover all aspects of the field from molecular and cellular biology to immunology and biochemistry, physiology to pathology, and paediatric to adult thyroid diseases with a special focus on thyroid cancer. Readers also benefit from reviews by noted experts, which highlight especially active areas of current research. The journal will further publish formal guidelines in the field, produced and endorsed by the European Thyroid Association.

\section{Submission}

Manuscripts written in English (the preferred wordprocessing package is MSWord ${ }^{\star}$ ) should be submitted using the online submission website at:

www.karger.com/etj
Editorial Office:
Wilmar M. Wiersinga, MD
S. Karger AG
Editorial Office 'European Thyroid Journal'
P.O. Box
CH-4009 Basel (Switzerland)
Tel. +41 613061424
Fax. +41 613061434
E-Mail etj@karger.ch

\section{Conditions}

All manuscripts must be accompanied by a covering letter signed by the corresponding author on behalf of all authors verifying that all the authors have made a significant contribution to the findings and methods in the paper. Assurance should be given that the manuscript is not under simultaneous consideration by any other publication. Presentation of manuscripts should conform with the Uniform Requirements for Manuscripts Submitted to Biomedical Journals (see N Engl J Med 1997;336:309-315).

All manuscripts are subject to editorial review. Submission of an article for publication implies the transfer of the copyright from the author to the publisher upon acceptance. Accepted papers become the permanent property of the European Thyroid Journal and may not be reproduced by any means, in whole or in part, without the written consent of the publisher. It is the authors' responsibility to obtain permission to reproduce illustrations, tables, etc. from other publications.

\section{Sections}

The journal consists of following sections:

1. Editorials

2. Guidelines

3. Basic Thyroidology - Reviews or Original Papers

4. Translational Thyroidology - Reviews or Original Papers

5. Clinical Thyroidology - Reviews or Original Papers 6. Letters to the Editor

Authors should indicate the section and category they wish their article to be considered for.

\section{Arrangement}

Pages should be numbered throughout the manuscript text.

Title page: The first page of each paper should indicate the title, the authors' names, the institute(s) where the work was conducted, a short title for use as running head and a conflict of interest statement.

Full address: The exact postal address of the corresponding author complete with postal code must be given at the bottom of the title page. Please also supply phone and fax numbers, as well as an e-mail address.

Key words: Please supply 3-10 key words in English that reflect the content of the paper.

Abstract: Each paper needs an abstract of up to 250 words and should be structured as follows:

Background: What is the major motive that prompted the study?

Objectives: What is the purpose of the study?

Methods: How was the study done?

Results: $\quad$ Most important findings.

Conclusions: Most important conclusions.

Footnotes: Footnotes should be avoided. When essential, they are numbered consecutively and typed at the foot of the appropriate page.

Tables and illustrations: Tables and illustrations (both numbered in Arabic numerals) should be prepared on separate pages. Tables require a heading and figures a legend. Due to technical reasons, figures with a screen background should not be submitted. When possible, group several illustrations in one block for reproduction (max. size $180 \times 223 \mathrm{~mm}$ ) or provide crop marks. Electronically submitted $b / w$ half-tone and color illustrations must have a final resolution of $300 \mathrm{dpi}$ after scaling (final size), line art drawings one of 800-1,200 dpi. Figure files should not be embedded in a document file but submitted separately.

References: In the text identify references by Arabic numerals [in square brackets]. Material submitted for publication but not yet accepted should be noted as 'unpublished data' and not be included in the reference list. The list of references should include only those publications which are cited in the text. Do not alphabetize; number references in the order in which they are first mentioned in the text. The surnames of the authors followed by initials should be given. There arate the authors. Preferably, please cite all authors. Abbreviate journal names according to the Index Medicus system. Also see International Committee of Medical Journal Editors: Uniform requirements for manuscripts submitted to biomedical journals (www. icmje.org). Authors using EndNote ${ }^{\circledast}$ may choose the format setting for Intervirology for the correct format of references.

\section{Examples}

(a) Papers published in periodicals: Vilhelmsson M, Johansson C, Jacobsson-Ekman G, Crameri R, Zargari A, Scheynius A: The Malassezia sympodialis allergen Mala s 11 induces human dendritic cell maturation, in contrast to its human homologue mangashould be no punctuation other than a comma to sep- nese superoxide dismutase. Int Arch Allergy Immunol 2007;143:155-162.

(b) Papers published only with DOI numbers: Theoharides TC, Boucher W, Spear K: Serum interleukin-6 reflects disease severity and osteoporosis in mastocytosis patients. Int Arch Allergy Immunol DOI: $10.1159 / 000063858$.

(c) Monographs: Matthews DE, Farewell VT: Using and Understanding Medical Statistics, ed 4, revised.

(d) Edited books: Bartalena L: Prevention; in Wiersinga WM, Kahaly GJ (eds): Graves' Orbitopathy: A Multidisciplinary Approach - Questions and Answers, ed 2, revised. Basel, Karger, 2010, pp 248-254.

\section{Ethics}

Published research must comply with the guidelines for human studies and animal welfare regulations. Authors should state in the 'Materials and Methods' section that subjects have given their informed consent and that the study protocol has been approved by the institute's committee on human research and thus meets the standards of the Declaration of Helsin$\mathrm{ki}$ in its revised version of 1975 and its amendments of 1983, 1989, and 1996 [JAMA 1997;277:925-926]. Information suitable to reveal the subject's identity is to be avoided. Further, they should also state that animal experiments conform to institutional standards. Copies of these guidelines and policy statements must be available for review by the editors if necessary.

\section{Disclosure Statement}

Authors are required to disclose any sponsorship or funding arrangements relating to their research and all authors should disclose any possible conflicts of interest. Conflict of interest statements should be placed on the title page, but will be published at the end of the article.

\section{Digital Object Identifier (DOI)}

S. Karger Publishers supports DOIs as unique identifiers for articles. A DOI number will be printed on the title page of each article. DOIs can be useful in the future for identifying and citing articles published online without volume or issue information. More information can be found at www.doi.org.

\section{Supplementary Material}

Supplementary material is restricted to additional data that are not necessary for the scientific integrity and conclusions of the paper. Please note that all supplementary files will undergo editorial review and should be submitted together with the original manuscript. The Editors reserve the right to limit the scope and length of the supplementary material. Supplementary material must meet production quality standards for Web publication without the need for any modification or editing. In general, supplementary files should not exceed $10 \mathrm{MB}$ in size. All figures and tables should have titles and legends and all files should be supplied separately and named clearly. Acceptable files and formats are: Word or PDF files, Excel spreadsheets (only if the data cannot be converted properly to a PDF file), and video files (.mov, .avi, .mpeg). Basel, Karger, 2007.

\section{KARGER}

Fax +41 613061234

www.karger.com
E-Mail karger@karger.ch
(C) 2012 European Thyroid Association

Published by S. Karger AG, Basel
www.karger.com/etj_Guidelines 


\section{Author's Choice ${ }^{\mathrm{TM}}$}

Karger's Author's Choice ${ }^{\mathrm{TM}}$ service broadens the reach of your article and gives all users worldwide free and full access for reading, downloading and printing at www.Karger.com. The option is available for a onetime fee of CHF 3000.-, which is a permissible cost in grant allocation. More information can be found at www.karger.com/authors_choice.

\section{NIH-Funded Research}

The U.S. National Institutes of Health (NIH) mandates under the NIH Public Access Policy that final, peer-reviewed manuscripts appear in its digital database within 12 months of the official publication date. As a service to authors, Karger submits the final version of your article on your behalf to PubMed Central. For those selecting our premium Author's Choice $^{\mathrm{TM}}$ service, we will send your article immediately upon publishing, accelerating the accessibility of your work without the usual embargo. More details on NIH's Public Access Policy is available at http:// publicaccess.nih.gov/FAQ.htm\#a1.

\section{Self-Archiving}

Karger permits authors to archive their pre-prints (i.e. pre-refereeing) or post-prints (i.e. final draft post-refereeing) on their personal or institution's servers, pro- vided the following conditions are met: Articles may not be used for commercial purposes, must be linked to the publisher's version, and must acknowledge the publisher's copyright. Authors selecting Karger's Author's Choice ${ }^{\mathrm{TM}}$ feature, however, are also permitted to archive the final, published version of their article, which includes copyediting and design improvements as well as citation links.

\section{Color Illustrations}

Online edition: Color illustrations are reproduced free of charge. In the print version, the illustrations are reproduced in black and white. Please avoid referring to the colors in the text and figure legends. Print edition: Up to 6 color illustrations per page can be integrated within the text at CHF 800.00 per page. The inability to pay the color charges will not necessarily prejudice reproduction of the figures in color; this will be decided on by the Editor.

\section{Copy Editing}

All manuscripts accepted for publication are subject to copy editing. Changes introduced by the copy editor and/or questions will be marked in the manuscript so please be sure to check the proofs against the manuscript. The copy edited manuscript will be returned along with the proofs.

\section{Proofs}

Unless indicated otherwise, proofs are sent to the corresponding author and should be returned with the least possible delay. Alterations made in proofs, other than the correction of printer's errors, are charged to the author. No page proofs are supplied.

\section{E-pub First}

All articles are published electronically ahead of print with a DOI number and are supplemented later with the definite reference of the printed version. The articles become available immediately after the authors' approval to publication, with the added advantage of being citable much earlier than in print. Authors can influence the time of appearance by promptly returning the proofs.

\section{Reprints}

An order form and a price list are sent with the proofs. Orders submitted after the release of an article in print are subject to considerably higher prices.

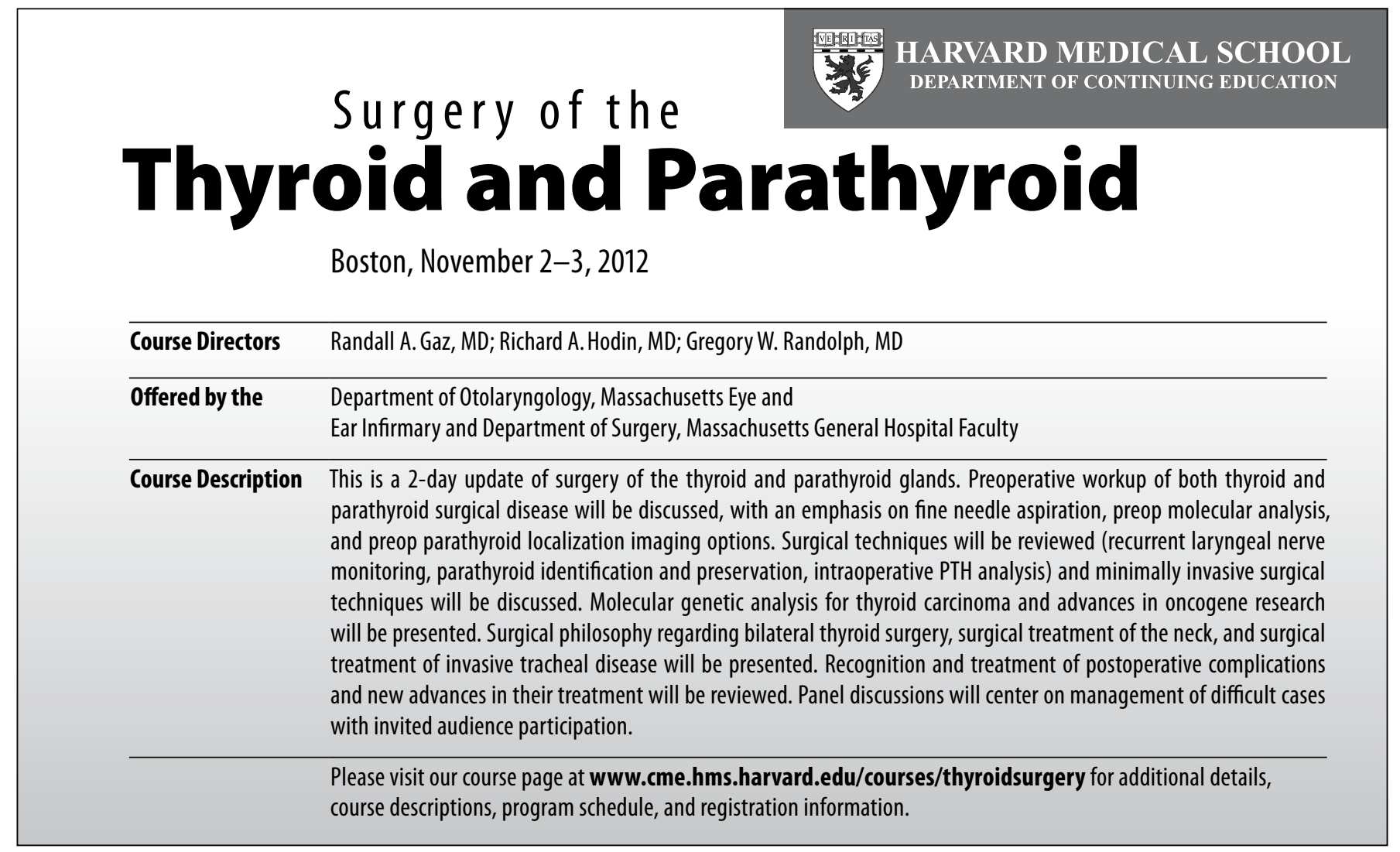

\section{KARGER}

Fax +4161306 1234 E-Mail karger@karger.ch www.karger.com
C) 2012 European Thyroid Association

Published by S. Karger AG, Basel

The Guidelines for Authors are available at: www.karger.com/etj_Guidelines 


\section{European Thyroid Journal}

ISSN Print Edition: 2235-0640

ISSN Online Edition: 2235-0802

Journal Homepage: www.karger.com/etj

Publication Data: European Thyroid Journal is published 4 times a year. Volume 1 with 4 issues, appears in 2012 .

Copyright: (C) 2012 European Thyroid Association. Published by S. Karger AG, Basel (Switzerland). All rights reserved. No part of this publication may be translated into other languages, reproduced or utilized in any form or by any means, electronic or mechanical including photocopying, recording, microcopying, or by any information storage and retrieval system, without permission in writing from the publisher or, in the case of photocopying, direct payment of a specified fee to the Copyright Clearance Center.

Disclaimer: The statements, opinions and data contained in this publication are solely those of the individual authors and contributors and not of the publisher and the editor(s). The appearance of advertisements in the journal is not a warranty, endorsement, or approval of the products or services advertised or of their effectiveness, quality or safety. The publisher and the editor(s) disclaim responsibility for any injury to persons or property resulting from any ideas, methods, instructions or products referred to in the content or advertisements.
Subscription Rates: Subscriptions run for a full calendar year. Prices are given per year. Personal subscription:

Print or Onlin

CHF 256.-

EUR 205.-

Print + Online combined

USD 249.00

CHF 304.-

EUR 243.-

USD 296.00

postage and handling (added to print and print+online)

CHF 27.20 Europe, CHF 40.- Overseas

EUR 20.80

USD 37.60

Institutional subscription:

Print or Online

Print+Online combined

CHF 1279.-

EUR 1023.-

CHF 1407.

USD 1242.00

EUR 1126.-

USD 1366.00

CHF 34.- Europe, CHF 50.- Overseas

EUR 26.-

USD 47.00

Airmail surcharge: CHF 34.- / USD 32.00

Discount subscription prices:

Please enquire about reduced rates for members of related societies.
Back Volumes and Single Issues: Information on availability and prices of single print issues and print or electronic back volumes can be obtained from Customer Service at service@karger.ch.

Bibliographic Indices: This journal is regularly listed in bibliographic services.

Photocopying: This journal has been registered with the Copyright Clearance Center (CCC), as indicated by the code appearing on the first page of each article. For readers in the US, this code signals consent for copying of articles for personal or internal use, or for the personal or internal use of specific clients, provided that the stated fee is paid per copy directly to

Copyright Clearance Center Inc.

222 Rosewood Drive

Danvers, MA 01923 (USA)

A copy of the first page of the article must accompany payment. Consent does not extend to copying for general distribution, for promotion, for creating new works, or for resale. In these cases, specific written permission must be obtained from the copyright owner,

S. Karger AG, P.O. Box

CH-4009 Basel (Switzerland).

\section{Subscription Orders:}

Orders can be placed at agencies, bookstores, directly with the Publisher

\section{S. Karger AG}

Medical and Scientific Publishers

P.O. Box

CH-4009 Basel

Switzerland

(for courier services only:

Allschwilerstrasse 10

CH-4055 Basel)

t: +41613061111

f: +41613061234

e: karger@karger.ch

w: www.karger.com or further Karger offices

or representatives:

Germany

S. Karger GmbH

Postfach

79095 Freiburg

Deutschland

(Hausadresse: Wilhelmstrasse 20A

79098 Freiburg)

$\mathrm{t}: \quad+49761452070$

f: +497614520714

e: information@karger.de

w: www.karger.de

Japan

Karger Japan, Inc

Shiba Daimon Asahi Bldg. 2F

1-2-23 Shiba Daimon

Minato-ku

Tokyo 105-0012

Japan

t: +81364356242

f: +81364356244

e: publisher@karger.jp

w: www.karger.jp

Change of Address:

Both old and new address should be sent

to the subscription source.

USA

S. Karger Publishers, Inc.

26 West Avon Road

P.O. Box 529

Unionville, CT 06085

USA

Toll free: +18008285479

t: +18606757834

$\mathrm{f}: \quad+18606757302$

e: karger@snet.net

France

Librairie Médi-Sciences Sarl

36, bd de Latour-Maubourg

75007 Paris

France

t: $+33(0) 145514258$

f: $+33(0) 145560780$

e: librairie@medi-sciences.fr

e: librairie@medi-sciences.

Gulf Council Countries, Iran,

Middle East, North Africa, Turkey

Trans Middle East International

Distribution Co. Ltd.

KaSha

134 Queen Rania Al Abdullah Street

Jordan Trade Center Bldg. 3rd Floor

P.O. Box 2376

Amman 11953

Jordan

t: +96265153467

f: +96265153472

e: info@kasha.cc

w: www.KaShaonline.com
South East Asia, China and Taiwan Karger Regional Office (Malaysia)

CEO Suite Kuala Lumpur

Quill 7, 27th Floor

Jalan Stesen Sentral 5

KL Sentral

Kuala Lumpur 50470

Malaysia

$\mathrm{t}:+60327766803$

f: +60327766999

e: service@karger.cn; r.chew@karger.cn

Karger China

10th Floor, Twin Towers (East)

B12 Jianguomenwai Avenue

Beijing 100022

$\mathrm{t}:+861051235033$

f: +861051235122

e: service@karger.cn; r.chew@karger.cn

w: www.karger.cn

India, Bangladesh, Sri Lanka

Medscience India

Plot No. 17, Yusuf Sarai Market

B.L. Glass Building, 2nd Floor

Sri Aurobindo Marg

New Delhi 110016

India

t: +911146029633

f: +911146029634

c: +919891052128

e: medsci.india@gmail.com

\section{KARGER}

Fax +41 613061234

E-Mail karger@karger.ch

www.karger.com
(C) 2012 European Thyroid Association

Published by S. Karger AG, Basel

The Journal Home Page is available at www.karger.com/etj 


\section{Contents}

See the journal website for contents

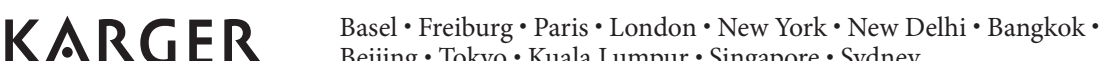
Beijing $\cdot$ Tokyo $\cdot$ Kuala Lumpur $\cdot$ Singapore $\cdot$ Sydney 


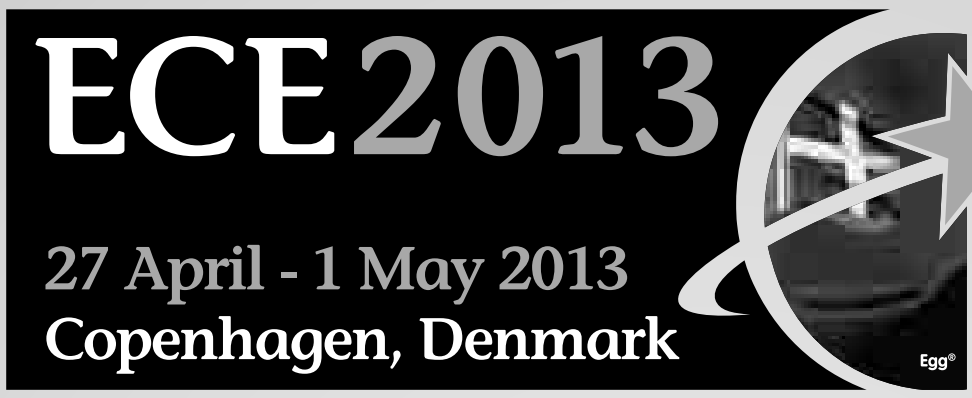

15th EUROPEAN CONGRESS OF ENDOCRINOLOGY

27 April - 1 May 2013

COPENHAGEN, DENMARK

FIRST

ANNOUNCEMENT AND WELCOME TO COPENHAGEN

European Society of Endocrinology the European hormone society 


\section{Intensivkurs Schilddrüsenerkrankungen}

Düsseldorf 02. bis 04. November 2012

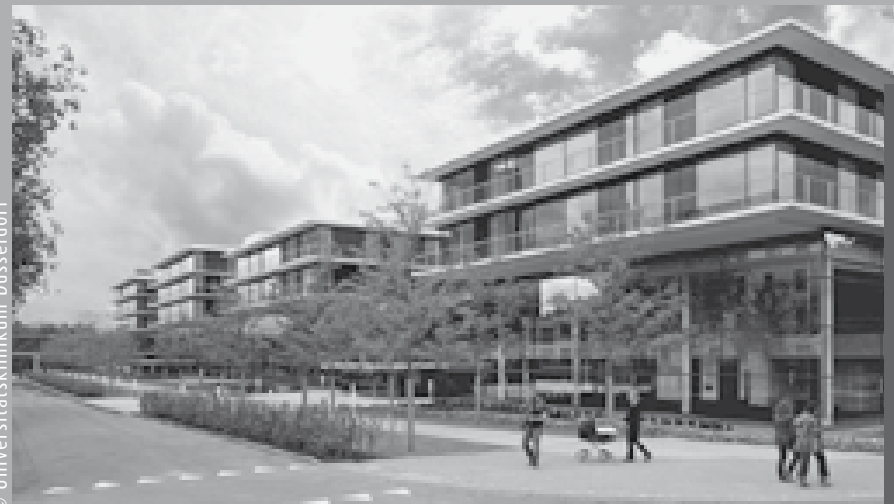

Universitätsklinikum Düsseldorf Hörsaalgebäude der MNR-Klinik

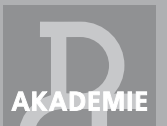

WISSENSCHAFTLICHE LEITUNG

Prof. Dr. Matthias Schott, Düsseldorf

Priv. Doz. Dr. Joachim Feldkamp, Bielefeld

TAGUNGSGEBÜHR

(inkl. Tagungsunterlagen, Kaffee- und Mittagspausen

Niedergelassene/Fachärzte

Hauptkurs

Sonographiekurs:

$350,-€$

$75,-€$

Assistenzärzte

Hauptkurs

Sonographiekurs"

Studenten" (nur Hauptkurs)

$200,-€$

$75,-€$

$100,-€$

"Nur in Zusammenhang mit dem Hauptkurs, begrenzte Teilnehmerzahl

Bescheinigung erforderlich (bitte an 09187-97 42474 faxen)

Weitere Information und Anmeldung

bei http://www.endokrinologie.net/veranstaltungen.php\#02.11.12-04.11.12

Organisation: Endoscience Endokrinologie Service GmbH, Hopfengartenweg 19, 90518 Altdorf E-Mail: info@endoscience.de

F12687

07.11. - 10.11.

2012

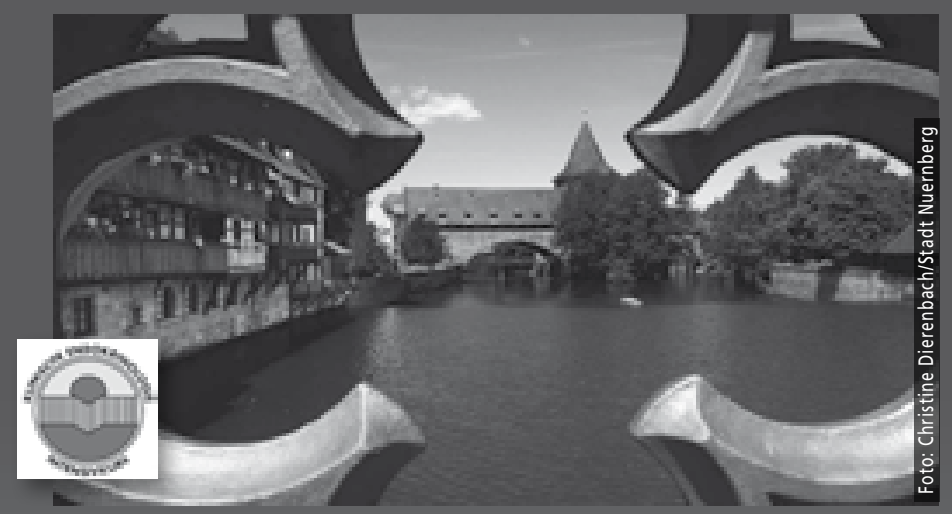

xv. Intensivkurs für

Klinische Endokrinologie

Holiday Inn NÜRNBERG

\section{Hauptthemen}

Schilddrüse

Nebenschilddrüse und

Knochenstoffwechsel

Hypophyse und Nebenniere

Übergang Adoleszenz/Erwachsenenalter

Diabetes mellitus und Stoffwechsel

Gonaden

Update klinische Studien 2011/2012

\section{Meet the Expert Sessions}

\section{Workshops}

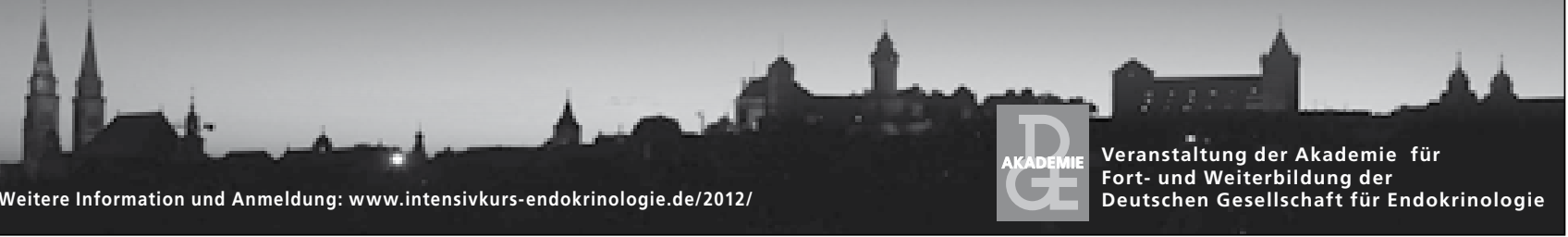




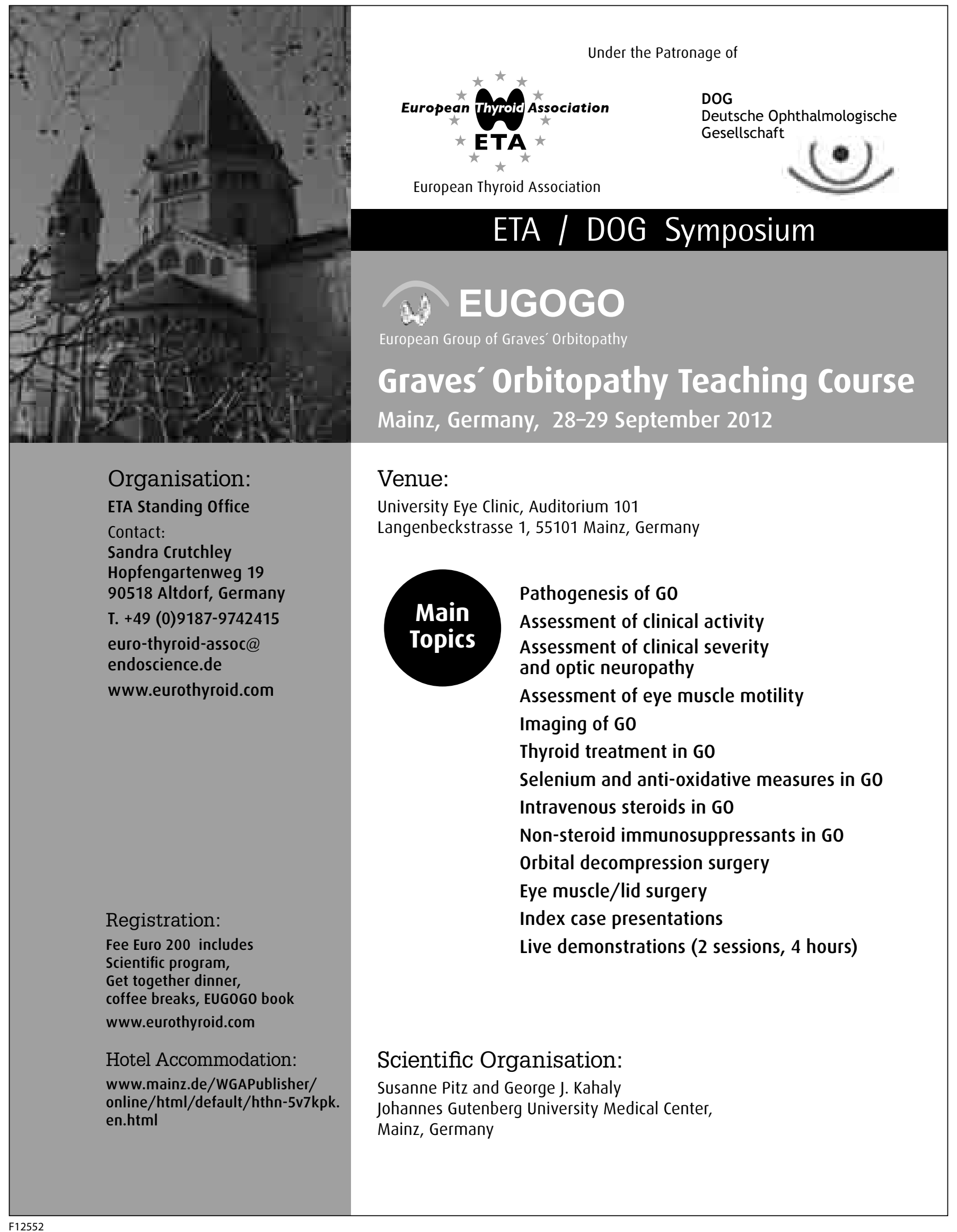



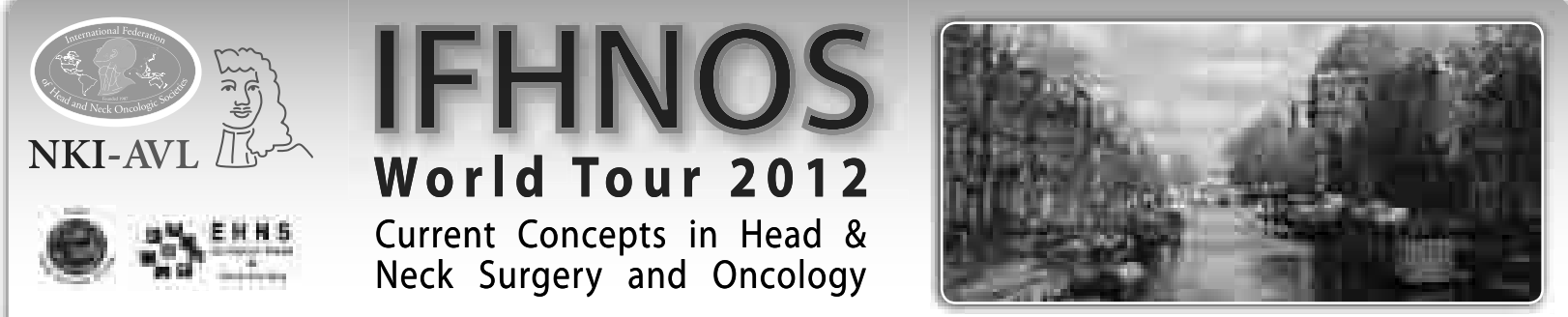

\section{4-6 October, 2012 | Novotel Amsterdam | www.ifhnosamsterdam2012.org}

The International Federation of Head and Neck Oncologic Societies together with the Netherlands Cancer Institute is proud to present you the Global Continuing Education Symposium on 'Current Concepts in Head and Neck Surgery and Oncology'.

Amsterdam is the only location in Western Europe for the World Tour 2012

Join your wordwide colleagues otolaryngologists, head and neck surgeons, radiotherapists, oncologists maxillofacial \& general surgeons and residents who have already registered from Austria, Belgium, Czech Republic, France, Germany, Italy, the Netherlands, New Zealand, Portugal, Spain, Switzerland, Sweden, United Kingdom and the United States.

\section{Conference Highlights}

- State-of-the-art knowledge on head and neck cancer diagnosis and treatment.

- Ample opportunities for intense interactive discussions between the traveling faculty members, regional experts and attendees.

- Case presentations and demonstrations of operative techniques through video sessions.

${ }^{*} \mathrm{CME}$ accreditation will be applied for this educational program.

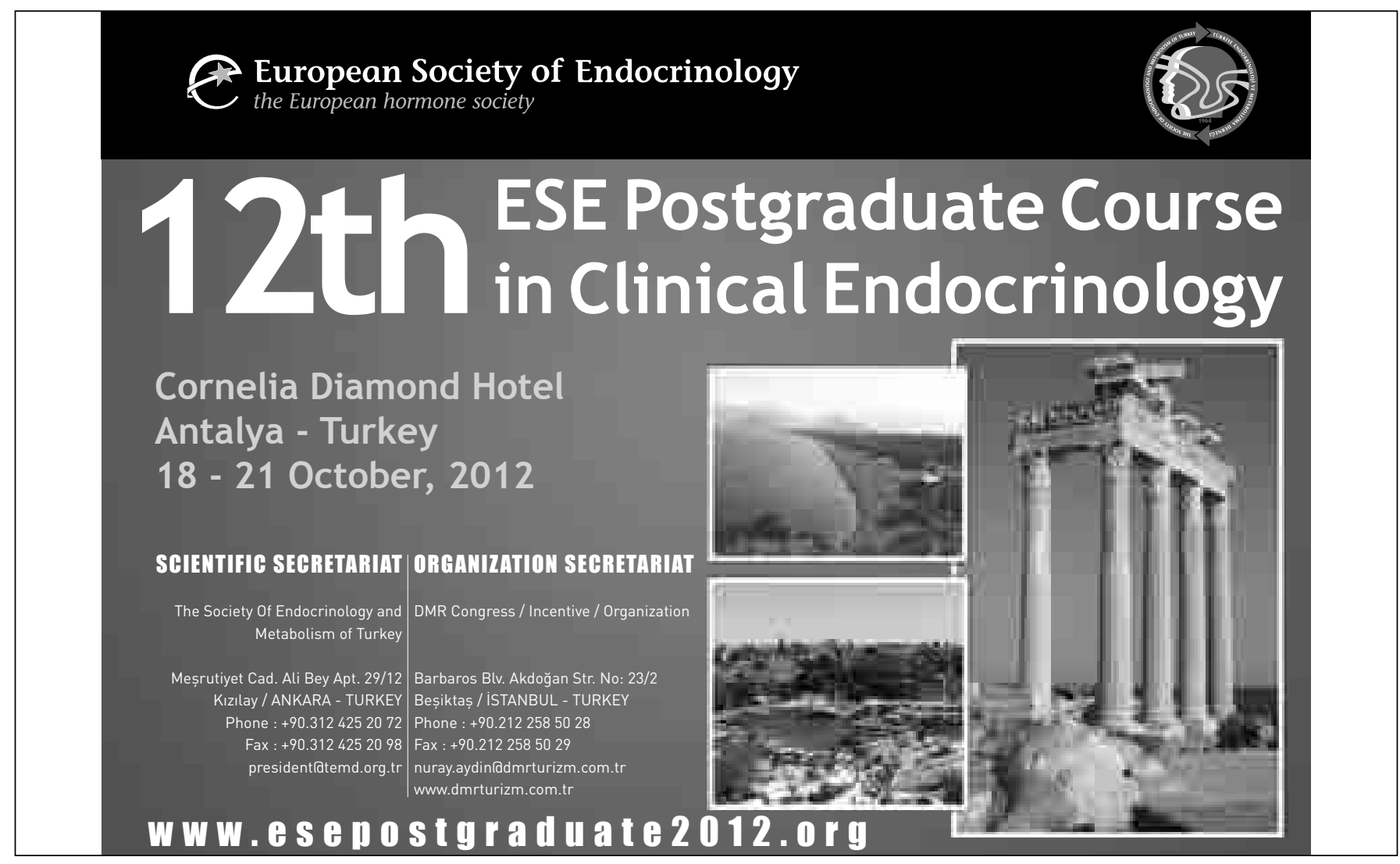




\section{The Sagond World}

Bongress on

Thyroid bancer

July 10-14, 2013

Sheraton Centre Toronto

Toronto, Ontario

Canada

A Multi Disciplinary Congress with

Leaders in the Field Instructional Courses

Panel Discussions

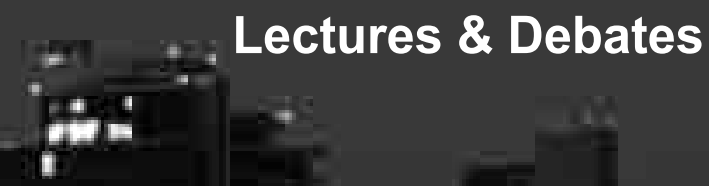

ins
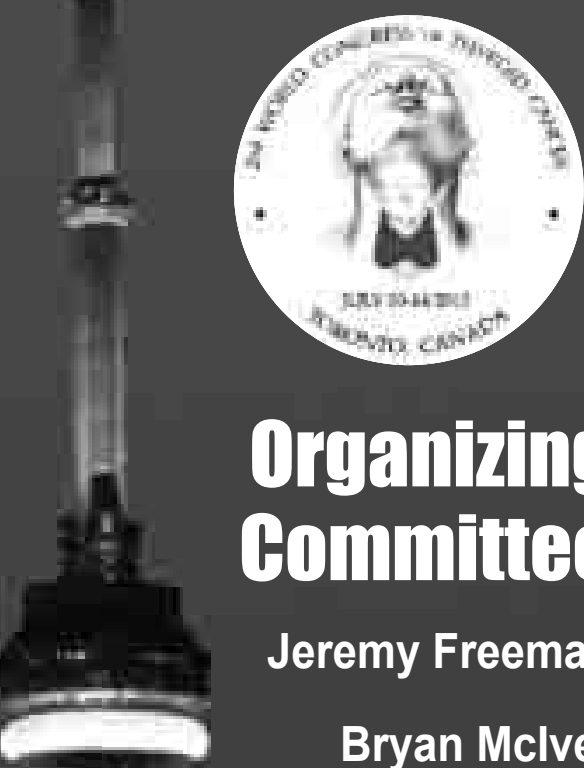

\section{Organizing Bommitios}

Jeremy Freeman

Bryan Mclver

Gregory W. Randolph

Jatin P. Shah

Ashok R. Shaha

Steven I. Sherman

R. Michael Tuttle

lan J. Witterick

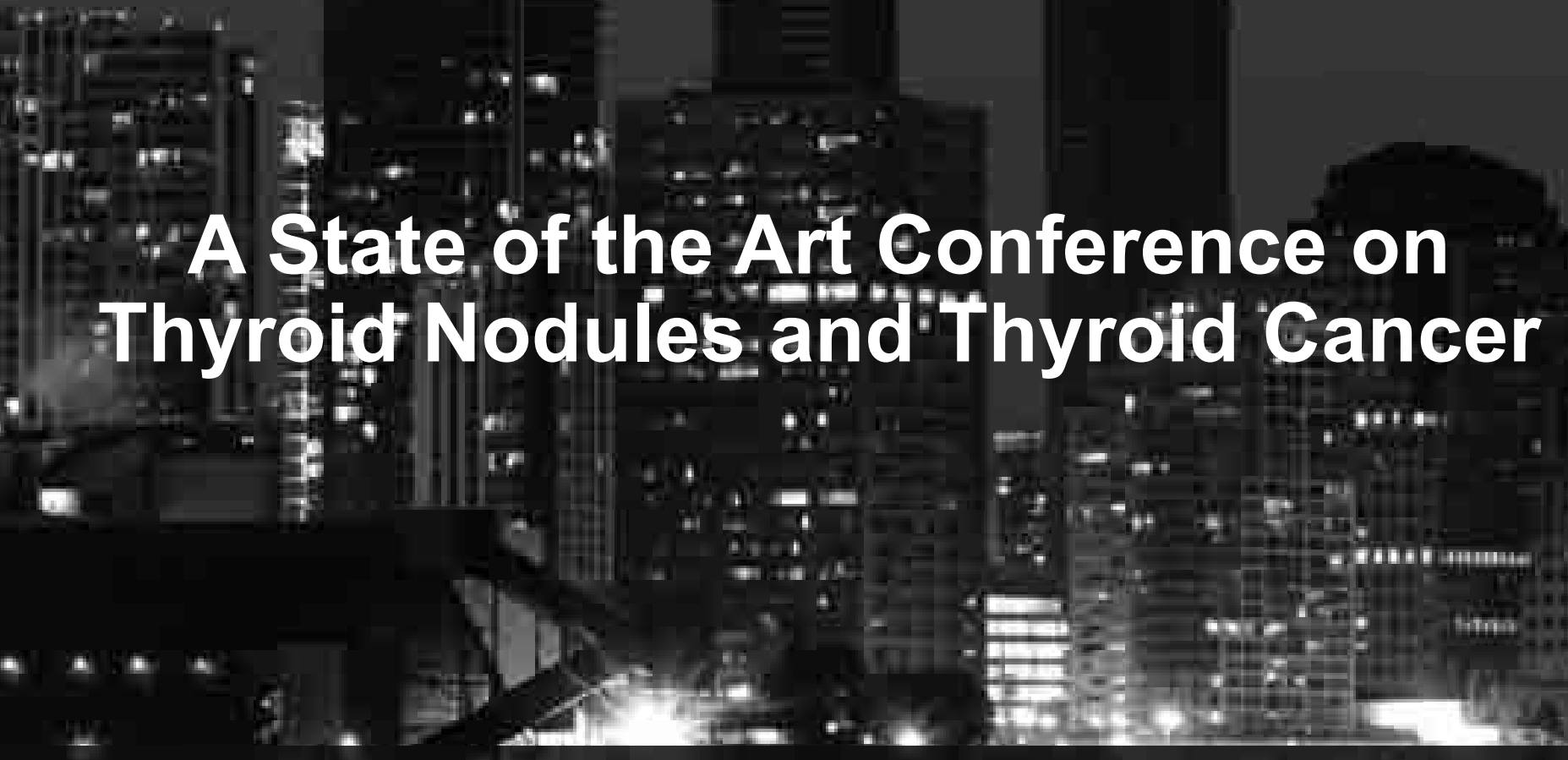

For Information Contact:

Congress Secretariat World Congress on Thyroid Cancer Phone: 1.519.263.5050 - Email: info@thyroidworldcongress.com www.thyroidworldcongress.com 


\section{Thoroughly updated 2nd edition \\ of this highly recommended book}

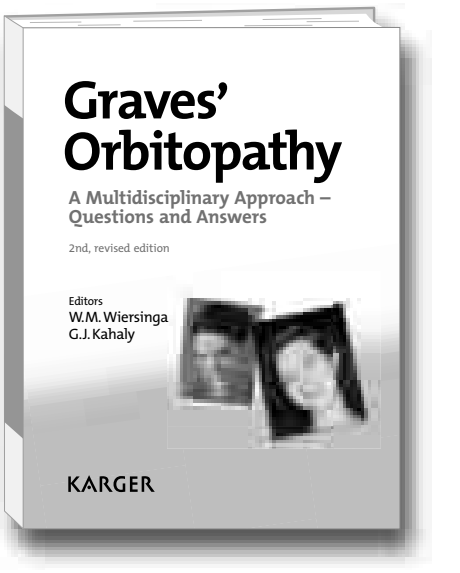

The significant progress in the understanding of the pathogenesis and the treatment of Graves' orbitopathy (GO) has warranted a second edition of this book within three years of the first. Now also fully incorporated is the EUGO$\mathrm{GO}$ consensus statement on management of $\mathrm{GO}$, which since has been accepted worldwide as a useful guideline. Furthermore all chapters have been thoroughly updated. Subjects covered include the pathology of GO and the controversial views on its pathogenesis; assessment of changes using reliable measuring techniques; medical management of GO including established and alternative treatment options; technical explanations and illustrations of various surgical procedures and finally, the molecular, immunologic, and clinical aspects of this complex disorder. Two new chapters have been added: one describing the socioeconomic impact of the disease and the other outlining the Amsterdam Declaration on Graves' Orbitopathy.

The successful question-and-answer format facilitates its use as a reference guide for medical practitioners and surgeons working in the fields of ophthalmology, internal medicine, endocrinology, pediatrics, immunology, as well as otorhinolaryngology.

\section{Graves' Orbitopathy A Multidisciplinary Approach - Questions and Answers}

2nd, revised edition

\author{
Editors \\ Wilmar M. Wiersinga \\ Georges J. Kahaly
}

\section{Contents}

Preface to the 2nd, Revised Edition: Wiersinga, W.M.; Kahaly, G.J.

Preface to the 1st Edition: Wiersinga, W.M.; Kahaly, G.J.

\section{Diagnosis and Pathogenesis}

Clinical Manifestations: Dickinson, A.J.

Orbit-Thyroid Relationship: Lazarus, J.H.; Marino, $M$.

Epidemiology: Daumerie, $C$.

Pathogenesis: Orgiazzi, J.; Ludgate, $\boldsymbol{M}$.

Orbital Imaging: Pitz, $\mathbf{S}$.

Diagnosis and Differential Diagnosis of Graves' Orbitopathy: Mourits, M.P.

Natural History: Pearce, S.; Kendall-Taylor, $P$.

\section{Management}

General Management Plan: Boboridis, $\boldsymbol{K}$;; Perros, $P$.

Combined Thyroid-Eye Clinics: Wiersinga, W.M.

Thyroid Treatment: Marcocci, C.; Pinchera, $\boldsymbol{A}$. Management of Mild Graves' Orbitopathy: Salvi, M.; Currò, $\mathbf{N}$.
Management of Moderately Severe Graves' Orbitopathy: Kahaly, G.J.

Management of Very Severe Graves' Orbitopathy (Dysthyroid Optic Neuropathy): Lane, C.M.; Boschi, A.

Rehabilitative Surgery: Baldeschi, $L$.

Orbital Decompression: Baldeschi, $L$. Eye Muscle Surgery: $\mathbf{N a r d i ,} \boldsymbol{M}$.

Eyelid Surgery: Neoh, C.; Eckstein, A.

\section{Miscellaneous Issues}

Quality of Life: Wiersinga, W.M.

Socioeconomic Impact: Kahaly, G.J.

Atypical Manifestations: von Arx, $\mathbf{G}$.

Childhood Graves' Orbitopathy: Krassas, G.E.

Prevention: Bartalena, $L$.

Future Developments: Salvi, M.; Baldeschi, $L$.

The Amsterdam Declaration on Graves' Orbitopathy: Perros, $P$.

Historical Notes on Graves' Disease: Mourits, M.P.

Author Index Subject Index

www.karger.com

Graves' Orbitopathy
A Multidisciplinary Approach - Questions and Answers

2nd, revised edition

Editors: Wiersinga, W.M. (Amsterdam)

Kahaly, G.J. (Mainz)

$\mathrm{XVI}+286$ p., 95 fig., 53 in color, 41 tab., soft cover, 2010

CHF 159.- / EUR 133.- / USD 187.00

Prices subject to change

EUR price for Germany, USD price for USA only

ISBN 978-3-8055-9531-5

e-ISBN 978-3-8055-9532-2
Please send: __ copy/ies

Postage and handling free with prepayment

E Payment:

Please charge to my credit card

- $\square$ American Express $\square$ Diners $\quad \square$ Eurocard

$\square$ MasterCard

$\square$ Visa

- Card No.

$\boldsymbol{\sigma}$

ס

CVV/CVC

(3 digits in the signature field on the back of Visa and MasterCard)

$\square$ Check enclosed $\square$ Please bill me

Orders may be placed with any bookshop, subscription agency, directly with the publisher or through a Karger distributor
Fax: +41 613061234

S. Karger AG, P.O. Box, CH-4009 Basel (Switzerland)

E-Mail orders@karger.ch, www.karger.com

Name/Address: 


\section{New journal}

European

Thyroid Journal

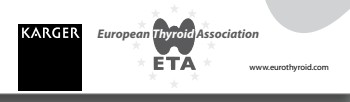

Editor-in-Chief

Wilmar M. Wiersinga,

Amsterdam

\section{Associate Editors}

Josef Koehrle, Berlin

(Basic Thyroidology)

Peter Laurberg, Aalborg

(Clinical Thyroidology)

Furio Pacini, Siena

(Thyroid Cancer)

Luca Persani, Milan

(Translational Thyroidology)

\section{Editorial Board}

Maria Alevizaki, Athens

Ana Aranda, Madrid

Rebecca Bahn, Rochester, Minn.

Paul Banga, London

Luigi Bartalena, Varese

Bernadette Biondi, Naples

Anita Boelen, Amsterdam

Georg Brabant, Lubeck

Henning Dralle, Halle

Murat Erdogan, Ankara

Valentin Fadeyev, Moscow

Ulla Feldt-Rasmussen,

Copenhagen

Laszlo Hegedus, Odense

George J. Kahaly, Mainz

Rui Maciel, São Paolo

Ana Luiza Maia, Porto Alegre

Jens Mittag, Stockholm

Ralf Paschke, Leipzig

Simon Pearce,

Newcastle-upon-Tyne

Robin P. Peeters, Rotterdam

Kris Poppe, Brussells

Samuel Refetoff, Chicago, III.

Jacques Samarut, Lyon

Pilar Santisteban, Madrid

Johannes Smit, Leiden

Mark Vanderpump, London

Theo Visser, Rotterdam

Paolo Vitti, Pisa

Graham R. Williams, London

Shunichi Yamashita, Nagasaki

Mariastella Zannini, Naples

\section{Call for papers}

\section{European \\ Thyroid Journal \\ Official Journal of the European Thyroid Association}

The European Thyroid Journal publishes papers reporting original research in basic, translational and clinical thyroidology. Original contributions cover all aspects of the field, from molecular and cellular biology to immunology and biochemistry, from physiology to pathology, and from pediatric to adult thyroid diseases with a special focus on thyroid cancer. Readers also benefit from reviews by noted experts, which highlight especially active areas of current research. The journal will further publish formal guidelines in the field, produced and endorsed by the European Thyroid Association.

\section{Call for papers}

The editors cordially invite you to submit your research papers to the European Thyroid Journal. Manuscripts written in English can be submitted online. Detailed Online Submission Instructions with a link to the Submission Website are at www. karger.com/eti. Before submitting your manuscript, you are encouraged to review the detailed guidelines at www. karger.com/eti_guidelines for specific directions as how to get a manuscript ready for submission.

\section{European Thyroid Journal}

2012: Vol. 1 with 4 issues

Language: English

ISSN 2235-0640

e-ISSN 2235-0802

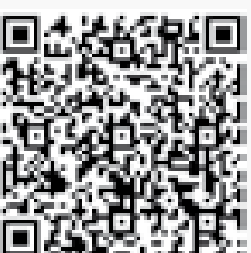

Official Journal of the

KARGER
European ThyroidAssociation 


\section{European Thyroid Journal}

Editorial

51 European Thyroid Association Guidelines on L-T4 + L-T3 Combination for Hypothyroidism: A Weary Step in the Right Direction

Perros, P. (Newcastle upon Tyne)

Guidelines

552012 ETA Guidelines: The Use of L-T4 + L-T3 in the Treatment of Hypothyroidism

Wiersinga, W.M. (Amsterdam); Duntas, L. (Athens); Fadeyev, V. (Moscow); Nygaard, B. (Herlev); Vanderpump, M.P.J. (London)

Basic Thyroidology

Review

72 Understanding the Hypothalamus-Pituitary-Thyroid Axis in Mct8 Deficiency

Müller, J.; Heuer, H. (Jena)

Translational Thyroidology

Reviews

80 Oxidative Stress in Graves' Disease

Marcocci, C.; Leo, M.; Altea, M.A. (Pisa)

88 Thyroid Hormone Replacement Therapy: Three 'Simple' Questions, Complex Answers

Bianco, A.C.; Casula, S. (Miami, Fla.)

Clinical Thyroidology

Original Papers

99 Alcohol Consumption as a Risk Factor for Autoimmune Thyroid Disease: A Prospective Study

Effraimidis, G.; Tijssen, J.G.P.; Wiersinga, W.M. (Amsterdam)
105 Is Recombinant Human TSH a Trigger for Graves' Orbitopathy?

Daumerie, C.; Boschi, A. (Brussels); Perros, P.

(Newcastle upon Tyne)

110 High Prevalence of Papillary Thyroid Microcarcinoma in Danish Patients: A Prospective Study of 854 Consecutive Patients with a Cold Thyroid Nodule Undergoing Fine-Needle Aspiration Rossing, M. (Herlev/Copenhagen); Nygaard, B. (Herlev); Nielsen, F.C. (Copenhagen); Bennedbæk, F.N. (Herlev)

118 Assessment of SPAG9 Transcript in Fine Needle Aspirates of Thyroid Nodules

Volard, B.; Krieger, S.; Planchard, G.; Hardouin, A.; Vaur, D.; Rame, J.-P.; Bardet, S. (Caen)

122 Greater Efficacy of Total Thyroidectomy versus Radioiodine Therapy on Hyperthyroidism and ThyroidStimulating Immunoglobulin Levels in Patients with Graves' Disease Previously Treated with Antithyroid Drugs

Kautbally, S.; Alexopoulou, O.; Daumerie, C.; Jamar, F.; Mourad, M.; Maiter, D. (Brussels)

Letters to the Editor

129 Polyneuropathy after Radioactive lodine Treatment of Hyperthyroidism and Beneficial Effect of Combined T4/T3 Therapy of Hypothyroidism Ivkovic, S. (Belgrade)

132 Thoughts about the 'Antenatal Thyroid Screening and Childhood Cognitive Function' Study Negro, R. (Lecce)

134 Reply

Lazarus, J.H. (Cardiff); Bestwick, J.P.; Wald, N.J. (London)

135 Use of $T_{4}, T_{4}+T_{3}$, and $T_{3}$ in the Dutch Population in the Period 2005-2011

de Jong, N.W.; Baljet, G.M. (Amersfoort)

54 Note 